УДК 657.1 .012

\author{
Іванченкова Л.В. \\ кандидат економічних наук, доцент \\ E-mail: I.ivanchenkova@mail.ru \\ Ткачук Г.О. \\ кандидат економічних наук, доцент \\ кафедра обліку та аудиту \\ Одеська національна академія харчових технологій \\ вул. Канатна, 112, м. Одеса, Україна, 65039 \\ E-mail: talla2007@ukr.net
}

\title{
ВНУТРІШНЬОГОСПОДАРСЬКА ЗВІТНІСТЬ В СИСТЕМІ УПРАВЛІННЯ БI3HECOM
}

Надана розгорнута характеристика внутрішньогосподарської звітності підприємства. Досліджено та проаналізовано ії різні категорії з авторським узагальненням. Систематизовано звітну внутрішню інформацію промислового підприємства. Виділено категорії розподілу обліково-аналітичної інформації, що вдосконалюють діючу систему управління підприємства. Наведено склад управлінської (внутрішньогосподарської) звітності для промислового підприємства.

Ключові слова: фрінансова звітність; внутрішньогосподарська (управлінська) звітність; функції звітності; бухгалтерський облік; управлінський облік.

This work is licensed under a Creative Commons Attribution 4.0 International License http://creativecommons.org/licenses/by/4.0/

Постановка проблеми та її зв'язок з важливими науковими та практичними задачами. В умовах необхідності побудови механізму антикризового управління в України дуже важливими постають питання ефективності системи менеджменту безпосередньо на виробничих підприємствах.

Управлінцям різних рангів необхідно приймати оперативні, відповідальні та дієві заходи щодо забезпечення безперебійної роботи підприємства в умовах інфляції та жорсткої конкуренції.

В умовах високого ритму господарських процесів рішення необхідно приймати дуже швидко, спираючись на внутрішню поінформованість. При цьому якість управлінської інформації грає майже першу скрипку в процесі поточного антикризового управління бізнесом.

Сучасна система бухгалтерського фінансового обліку не спроможна задовольнити зростаючі потреби їі користувачів [1]. Саме тому в сучасному бізнесі зростає роль управлінського обліку та управлінської звітності.

Аналіз останніх публікацій 3 проблеми. Нажаль серед вітчизняних науковців не існує єдиного підходу до визначення категорії «управлінська звітність». Ю.А. Кузьмінський, В.М. Добровський вважають основним джерелом інформації для управління фінансову звітність [2; 3]. В.В.Сопко зосереджується на бухгалтерській звітності, до складу якої відносить фінансову та інші види звітності [4]. Ф.Ф. Бутинець, Т.В. Давидюк, Н.М. Малюга, Л.В. Чижевська виділяють важливість для прийняття управлінських рішень фінансової та внутрішньої бухгалтерської звітності [5].

Сучасні науковці підкреслюють недосконалість діючої системи управлінського (внутрішньогосподарського) обліку та наявність таких ii недоліків, як: відсутність чіткої регламентації (П.Я. Хомин) [6]; необхідність якісного вдосконалення та кількісного різновидного розширення ( Т.М. Сторожук) [7]; неузгодженість показників різних форм звітності та відсутність методичного забезпечення (С.А. Кузнецова) [7].

Таким чином, запропонована тематика є актуальною, малодослідженою та цікавою для становлення управлінського обліку на підприємствах України.

Аналіз цілого ряду публікацій дає змогу визначити коло маловивчених питань, а саме питань, присвячених принципам та складу управлінської (внутрішньогосподарської) звітності на підприємствах харчової промисловості.

Формулювання цілей дослідження. До складу цілей дослідження відносимо: надання розгорнутої характеристики внутрішньогосподарської звітності підприємства 3 дослідженням та аналізом іiі категорій; систематизації звітної внутрішньої інформації підприємства; виділення категорій розподілу обліково-аналітичної інформації, що вдосконалюють діючу систему управління підприємства.

Виклад основних результатів та їх обгрунтування. Оскільки для визначення принципів, вимог та складу звітності, яка надає інформацію для цілей управління бізнесом підприємства, в економічній літературі використовуються різні поняття 
(управлінська звітність, внутрішня звітність, внутрішня бухгалтерська звітність, внутрішньогосподарська звітність, інтегрована управлінська звітність) перш за все систематизуємо існуючі авторські визначення досліджуваної категорії (табл.1).

Таблиця 1

Дослідження категорії «управлінська звітність» *

\begin{tabular}{|c|c|c|c|}
\hline Назва & Зміст & Автор & $\begin{array}{l}\text { Основні } \\
\text { аспекти }\end{array}$ \\
\hline $\begin{array}{l}\text { Внутрішня } \\
\text { звітність [9] }\end{array}$ & $\begin{array}{l}\text { система збору інформації в грошовому і нату- } \\
\text { ральному вимірі про факти господарської дія- } \\
\text { льності, які впливають не тільки на фінансові, а } \\
\text { й на виробничі й технологічні показники підп- } \\
\text { риємства, яка використовується для потреб } \\
\text { управління }\end{array}$ & А.С.Бакаєв & $\begin{array}{l}\text { Інформація в } \\
\text { грошовому і } \\
\text { натуральних } \\
\text { вимірниках }\end{array}$ \\
\hline $\begin{array}{l}\text { Внутрішня } \\
\text { бухгалтерська } \\
\text { звітність [5] }\end{array}$ & $\begin{array}{l}\text { звітність, яку складає бухгалтер-аналітик і по- } \\
\text { дає як адміністрації підприємства, так і мене- } \\
\text { джерам всіх рівнів управління }\end{array}$ & $\begin{array}{l}\text { Ф. Ф. Бутинець, } \\
\text { Т. В. Давидюк, } \\
\text { Н. М. Малюга, } \\
\text { Л. В. Чижевська }\end{array}$ & $\begin{array}{c}\text { Складається } \\
\text { бухгалтером- } \\
\text { аналітиком }\end{array}$ \\
\hline $\begin{array}{c}\text { Управлінська } \\
\text { (внутрішньогос- } \\
\text { подарська) } \\
\text { звітність }[10]\end{array}$ & $\begin{array}{l}\text { комплекс взаємопов'язаних даних і розрахун- } \\
\text { кових показників, що відображають функціо- } \\
\text { нування підприємства як суб'єкта господарсь- } \\
\text { кої діяльності, згрупованих загалом для підп- } \\
\text { риємства й у розрізі структурних підрозділів }\end{array}$ & Г.Брик & $\begin{array}{c}\text { Дані згруповано } \\
\text { за структурними } \\
\text { підрозділами і за } \\
\text { підприємством в } \\
\text { цілому } \\
\end{array}$ \\
\hline $\begin{array}{l}\text { Система } \\
\text { управлінської } \\
\text { звітності [11] }\end{array}$ & $\begin{array}{l}\text { сукупність відповідних форм звітності у взає- } \\
\text { мопов'язаних показниках за об'єктами обліку } \\
\text { для прийняття управлінських рішень. }\end{array}$ & Н.В.Тлучкевич & $\begin{array}{c}\text { Взаємопов’язані } \\
\text { показники }\end{array}$ \\
\hline $\begin{array}{l}\text { Внутрішньогос- } \\
\text { подарська } \\
\text { (управлінська) } \\
\text { звітність [12] }\end{array}$ & $\begin{array}{l}\text { інструмент управління господарством та ін- } \\
\text { струмент управління інформаційним забезпе- } \\
\text { ченням, а також елемент методу бухгалтерсь- } \\
\text { кого обліку, та документів, вміст яких предста- } \\
\text { вляє економічну інформацію у певному наборі } \\
\text { фактичних (історичних) та оціночних (розра- } \\
\text { хункових) показників для порівняння їх плано- } \\
\text { во-нормативних та досягнутих значень }\end{array}$ & Позов А.X. & $\begin{array}{l}\text { Інформація для } \\
\text { порівняння } 3 \\
\text { планово- } \\
\text { нормативним } \\
\text { значенням }\end{array}$ \\
\hline $\begin{array}{l}\text { Управлінська } \\
\text { звітність [13] }\end{array}$ & $\begin{array}{l}\text { систематизована обліково-аналітична інформа- } \\
\text { ція у вигляді облікових і розрахункових показ- } \\
\text { ників внутрішньо- фірмових формах і призна- } \\
\text { чена для внутрішніх користувачів } 3 \text { метою } \\
\text { прийняття ними управлінських рішень, не тіль- } \\
\text { ки поточного, але і стратегічного характеру }\end{array}$ & Попов А.Н. & $\begin{array}{c}\text { Систематизована } \\
\text { інформація }\end{array}$ \\
\hline $\begin{array}{l}\text { Управлінська } \\
\text { звітність [14] }\end{array}$ & $\begin{array}{l}\text { самостійна система надання даних, необхідних } \\
\text { для інформаційного забезпечення менеджменту }\end{array}$ & Шигун М. М. & $\begin{array}{c}\text { Система } \\
\text { інформаційного } \\
\text { забезпечення } \\
\text { менеджменту } \\
\end{array}$ \\
\hline $\begin{array}{l}\text { Управлінська } \\
\text { звітність [15] }\end{array}$ & $\begin{array}{l}\text { це звітність для внутрішніх користувачів, яка } \\
\text { включає інформацію про господарську діяль- } \\
\text { ність підприємства та умови їі здійснення, під- } \\
\text { готовлена } 3 \text { використанням методичних при- } \\
\text { йомів бухгалтерського обліку, планування, } \\
\text { аналізу, контролю й інших дисциплін }\end{array}$ & Король С. Я. & $\begin{array}{c}\text { Передбачає } \\
\text { використання } \\
\text { спеціальних } \\
\text { методичних } \\
\text { прийомів }\end{array}$ \\
\hline $\begin{array}{l}\text { Інтегрована } \\
\text { управлінська } \\
\text { звітність [8] }\end{array}$ & $\begin{array}{l}\text { сукупність поглядів, спосіб розуміння, тлума- } \\
\text { чення процесу узагальнення облікової інфор- } \\
\text { мації, що визначає стратегію дій у здійсненні } \\
\text { реформ для досягнення інтегрованості управ- } \\
\text { лінської звітності з метою комплексного інфо- } \\
\text { рмаційного забезпечення зовнішніх та внутрі- } \\
\text { шніх користувачів у процесі управління ком- } \\
\text { паніями }\end{array}$ & С.А.Кузнецова & $\begin{array}{c}\text { Процес } \\
\text { узагальнення } \\
\text { облікової } \\
\text { інформації. } \\
\text { Визначає } \\
\text { стратегію дій }\end{array}$ \\
\hline
\end{tabular}


Продовження таблиці 1

\begin{tabular}{|c|l|r|c|}
\hline & визначена система взаємопов’язаних економіч- & & Характеризує \\
Внутрішня & них показників, що характеризує результати & Т.О. Гуренко, & результати \\
звітність & підрозділів за певний проміжок часу і має на & С.І. Дерев’янко, & діяльності \\
підрозділів & меті надати результати діяльності підприємства & С.О. Олійник & підрозділів \\
{$[16]$} & або окремих його структурних підрозділів за & & \\
\hline
\end{tabular}

* Узагальнено авторами на основі [5, 8-16]

Аналізуючи дані вищевказаної таблиці, визначимо наступне:

1. Звітність для цілей управління грунтується на даних бухгалтерського обліку (первинного, оперативного, поточного, узагальнюючого, аналітичного та синтетичного) та вміщує аналітичні дані, тому $є$ продуктом обліково-аналітичної системи підприємства.

2. Звітність, що розглядається, надає інформацію для оперативного, поточного та стратегічного управління, тому являється управлінською.

3. Звітність, що розглядається, формується не тільки в бухгалтерії, а і в інших структурних підрозділах підприємства, які фіксують, накопичують та зберігають інформацію про господарські операції і процеси, тому є внутрішньогосподарською.

4. Управлінська (внутрішньогосподарська) звітність є елементом системи інформаційного забезпечення менеджменту.

5. Управлінська (внутрішньогосподарська) звітність використовує спеціальні методичні прийоми формування показників.

Аналізуючи позиційні підходи деяких авторів [17; 18; 19] до звітності і системі управління та враховуючи власний погляд виділяємо такі особливості системи управлінської звітності:

- представляє собою систему гнучкої обліково-аналітичної інформації для контролю, аналізу, укладання бюджетів, прийняття управлінських рішень;

- складається як за центрами відповідальності так і по підприємству в цілому; го рівня;

- надається управлінському персоналу різно-

- відображає умови, специфіку та особливості діяльності фірми; підприємства;

- будується відповідно до облікової політики

- задовольняє потреби управління.

Внутрішньогосподарська звітність призначена для прийняття оперативних управлінських рішень, контролю за їх виконанням, прогнозування та планування діяльності та для оцінки результатів виконаних рішень [20].

Для вдосконалення діючої системи управління пропонуємо поділити весь потік обліковоаналітичної інформації на три категорії:

1. Оперативна внутрішньогосподарська (управлінська) звітність.

2. Поточна внутрішньогосподарська (управлінська) звітність.

3. Узагальнююча внутрішньогосподарська (управлінська) звітність.
Кожний день управлінці різних рангів стикаються з необхідністю вирішення оперативних задач:

- термінової закупівлі сировини, матеріалів, пального, запасних частин, будівельних матеріалів, відсутність яких загрожує зупинити виробництво;

- погашення заборгованості перед постачальниками, бюджетом та іншими кредиторами, термін сплати якої вже настав;

- виконання зобов'язань по відвантаженню готової продукції та товарів;

- забезпечення встановлених санітарногігієнічних, технічних та технологічних норм організації виробництва;

- забезпечення безперебійної роботи та повного завантаження основних та допоміжних господарських структур;

- своєчасної ліквідації наслідків непередбачуваних збоїв в роботі підприємства (поламка обладнання; невідповідна якість сировини; відсутність транспортних засобів; хвороба провідних спеціалістів; збої у постачанні електроенергії, води, газу тощо);

- моніторингу господарських операцій, які загрожують падінню ефективності господарської діяльності (несвоєчасність постачання виробничих запасів, поламки обладнання, факти порушень технології тощо);

- формування пропозицій щодо вдосконалення системи поточного управління та планування діяльності.

Вищевказану інформацію в системі управління можна отримати саме за допомогою оперативної внутрішньогосподарської звітності.

В результаті поточного управління можна користуватись певним обсягом історичної інформації за більш довгий період, що дозволяє вносити певні коригування поточного планування процесів постачання, виробництва та реалізації та здійснити контроль за виконанням оперативних управлінських рішень. Інформаційним джерелом для таких дій є поточна внутрішньогосподарська звітність, яка представляє собою інформацію структурних підрозділів підприємства та бухгалтерії підприємства за тиждень, декаду або місяць.

Поточні внутрішньогосподарські звіти надають аналітичну інформацію про ритмічність поставок та відвантаження, матеріальне та технічне забезпечення виробництва, своєчасність розрахунків, структуру витрат діяльності, наявність небезпечних для діяльності факторів, ефективність прийнятих оперативних управлінських рішень. 
Узагальнюючі внутрішньогосподарські звіти укладаються різними підрозділами підприємства та відображають повний спектр результатів господарської діяльності: виконання бюджетів (економічний відділ), звіт про постачання та реалізацію (відділи постачання та збуту), звіт про технічне забезпечення (технічний відділ), звіт про якість продукції (технологічний відділ), звіт про випуск продукції (виробничий відділ), звіти про роботу допоміжних структур (звіт начальників транспортного, будівельного, енергетичного та інших відділів), звіт про розвиток інновацій (інноваційний відділ), звіт про фінансові результати (бухгалтерія), звіт про наявність заборгованості (бухгалтерія), звіт про забезпечення корпоративних інтересів (бухгалтерія) тощо.

Узагальнююча звітна інформація підлягає обробці в межах обліково-аналітичної системи підприємства і повинна подаватись управлінцям разом із аналітичними викладками (пояснювальними записками).

В табл. 2 представляємо склад управлінської (внутрішньогосподарської) звітності для промислового підприємства.

Таблиця 2

Склад управлінської звітності виробничого підприсмства*

\begin{tabular}{|c|c|c|}
\hline $\begin{array}{c}\text { Види } \\
\text { управлінської } \\
\text { звітності }\end{array}$ & $\begin{array}{c}\text { Загальна } \\
\text { характеристика }\end{array}$ & Склад управлінської звітності \\
\hline $\begin{array}{l}\text { 1.Оперативна } \\
\text { внутрішньогоспо- } \\
\text { дарська } \\
\text { звітність (щоденна) }\end{array}$ & $\begin{array}{l}\text { Грунтується на даних } \\
\text { аналітичного та } \\
\text { складського обліку. } \\
\text { Складається за } \\
\text { центрами відповіда- } \\
\text { льності, структурними } \\
\text { підрозділами підпри- } \\
\text { ємства. }\end{array}$ & $\begin{array}{l}\text { - оперативні звіти основних та допоміжних господарських } \\
\text { структур про залишки товарно-матеріальних цінностей (вироб- } \\
\text { ничих запасів, готової продукції, товарів тощо) - для забезпе- } \\
\text { чення управлінських рішень щодо постачання та збуту; } \\
\text { - оперативні звіти про хід виробничого процесу, процесу пос- } \\
\text { тачання та збуту готової продукції: наявність простоїв та браку } \\
\text { виробництва з визначенням причини та суми отриманого збит- } \\
\text { ку; } \\
\text { - оперативні звіти про залишки грошових коштів на поточних } \\
\text { та карткових рахунках та в касі підприємства; } \\
\text { - оперативні звіти про залишки термінової кредиторської забо- } \\
\text { ргованості; } \\
\text { - довідка про дотримання встановлених санітарно-гігієнічних, } \\
\text { технічних та технологічних норм організації виробництва. }\end{array}$ \\
\hline $\begin{array}{l}\text { 2.Поточна } \\
\text { звітність } \\
\text { (за тиждень, } \\
\text { декаду, місяць) }\end{array}$ & $\begin{array}{l}\text { Призначена для пото- } \\
\text { чного планування } \\
\text { грошових та товарних } \\
\text { потоків, формування } \\
\text { поточних бюджетів та } \\
\text { контролю виконання } \\
\text { управлінських рішень }\end{array}$ & $\begin{array}{l}\text { - поточні звіти про випуск продукції, виконання робіт, надання } \\
\text { послуг (виробничі звіти); } \\
\text { - поточні звіти про виконання кошторисів, норми витрат на } \\
\text { випуск продукції; } \\
\text { - поточні звіти матеріально-відповідальних осіб; } \\
\text { - поточні звіти про технічний стан та використання виробни- } \\
\text { чих потужностей підприємства; } \\
\text { - поточні звіти про якість продукції, наявність браку та рекла- } \\
\text { мацій; } \\
\text { - поточні звіти про ритмічність поставок сировини і матеріалів; } \\
\text { - план-графік поточних обов’язкових платежів (розрахунки з } \\
\text { постачальниками, з оплати праці, податках, обов'язкових пла- } \\
\text { тежах, тощо). }\end{array}$ \\
\hline $\begin{array}{l}\text { 3.Узагальнююча } \\
\text { звітність } \\
\text { (за місяць, } \\
\text { квартал, рік) }\end{array}$ & $\begin{array}{l}\text { Використовується для } \\
\text { здійснення контролю } \\
\text { ефективності бізнесу } \\
\text { та стратегічного пла- } \\
\text { нування }\end{array}$ & $\begin{array}{l}\text { - звіт про використання виробничих потужностей; } \\
\text { - звіт про забезпеченість робочою силою; } \\
\text { - звіт про ефективність матеріально-технічного забезпечення } \\
\text { (постачальники, відповідність якості сировини, ціновий рі- } \\
\text { вень); } \\
\text { - звіт про витрати виробництва та собівартість основних видів } \\
\text { продукції; } \\
\text { - звіт про рівень заробітної плати; } \\
\text { - звіт технічний стан обладнання, транспортних засобів, } \\
\text { комп’ютерної техніки; } \\
\text { - звіт про випуск та реалізацію продукції; } \\
\text { - звіт про результати інвентаризації; } \\
\text { - звіт про фінансовий стан (баланс) з аналітичними висновка- } \\
\text { ми; } \\
\text { - звіт про фінансові результати з аналітичними викладками. }\end{array}$ \\
\hline
\end{tabular}

* складено авторами 
На наш погляд, управлінська (внутрішньогосподарська) звітність $є$ продуктом обліковоаналітичної системи підприємства, включає в себе систему оперативних, поточних та узагальнюючих звітів, укладених за обліковими даними всіх структурних підрозділів підприємства, та аналітичних пояснень до них, що задовольняють потреби управління. Показники різних форм звітності мають бути взаємопов'язаними, доречними та достовірними, визначатись відповідно до обраної методики розрахунку та принципів облікової політики.

Висновки та перспективи подальших досліджень. В нашому дослідженні зроблено спробу систематизувати звітну внутрішню інформацію, яку 3 метою оперативного, поточного та стратегічного управління, контролю та планування мають використовувати промислові підприємства. Однак необхідно визначити, що в організації внутрішньогосподарської (управлінської) звітності все ще існують певні недоліки пов'язані із: відсутністю зовнішньої регламентації; неузгодженістю показників різних форм внутрішньогосподарської звітності; відсутність чіткої облікової політики щодо регламентації внутрішньої звітності; відсутністю чітких принципів корпоративної політики щодо мети та завдань оперативного та поточного управління; недостатнім рівнем обізнаності управлінців з питань інформативності обліково-аналітичної системи підприємства (системи обліку, аналізу та контролю); відсутність методичного забезпечення формування управлінської звітності.

Саме ці питання $є$ основою майбутніх наукових досліджень системи формування показників, обробки та передачі інформації для інформаційного забезпечення менеджменту.

\section{Література}

1. Мних Є.В. Становлення і перспективи розвитку сучасної системи бухгалтерського обліку і аудиту в Україні / Є.В. Мних // Світ бухгалтерського обліку. - 1997. - № 1. - С. 32-37.

2. Бухгалтерський облік для економістів і правознавців: [навч. посіб] / [Л.С. Берадзе, Т.А. Бондар, М.О. Воронова та ін.] ; за заг. ред. Ю.А. Кузьмінського. - К.: КНЕУ, 2007. - 648 с.

3. Добровський В.М. Звітність підприємств: [навч.-метод. посібник для самост. вивч. дисц.] / В.М. Добровський. - К.: КНЕУ, 2001. -195 с.

4. Сопко В.В. Бухгалтерський облік в управлінні підприємством: [навч. посіб] / В.В. Сопко. - К.: KHEУ, 2006. $-526 \mathrm{c}$.

5. Бухгалтерський управлінський облік: підручник для студентів спеціальності 7.050106 «Облік і аудит» вищих навчальних закладів / [Ф.Ф. Бутинець, Т.В. Давидюк, Н.М. Малюга, Л.В. Чижевська]; за ред. проф. Ф.Ф. Бутинця. - [2-е перероб. і доп.]. - Житомир: ПП «Рута», 2002. - 480 с.

6. Хомин П.Я. Формування звітності в підсистемах фінансового, управлінського й податкового обліку: [монографія] / П.Я.Хомин. - Тернопіль: Економічна думка, 2004. - 288с.

7. Сторожук Т. М. Внутрішньогосподарська звітність підприємства: матеріали міжн. наук.-практ. конф. «Научная мысль информационного века - 2012» : Экономические науки. - 2012 [Електронний ресурс]. - Режим доступа : http://www. rusnauka.com/8_NMIW_2012/Economics/.

8. Кузнецова С.А. Інтегрована управлінська звітність: глобальні виклики та локальні рішення в епоху ноосфери / С.А. Кузнецова.- Економічний нобелівський вісник. 2014. № 1 (7). - С. 270-279.

9. Бакаев А.С. Толковый бухгалтерский словарь / А.С.Бакаев. - М.: Бухгалтерский учет, 2006. -164 с.

10. Брик Г. Управлінська (внутрішньогосподарська) звітність аграрних формувань [Електронний ресурс]. - Режим доступу : Vinau_econ_2014_21(1)_18.pdf-Foxit Reader.

11. Тлучкевич Н.В. Формування системи внутрішньої управлінської звітності в сільськогосподарських підприємствах / Н.В. Тлучкевич // Економіка АПК. - 2008. - №9. - С. 82-88.

12. Позов А. Х. Формування внутрішньогосподарської (управлінської) звітності промислових підприємств : автореф. дис. канд. ек. наук : спец. 08.00 .09 - «Бухгалтерський облік, аналіз та аудит (за видами економічної діяльності)» / А. Х. Позов. - К., 2013. -22 с.

13. Попов А. Н. Управленческая отчетность: критический анализ существующих подходов и определений / А. Н. Попов // Фундаментальные исследования. - 2012. - № 6. - С. 753 - 757.

14. Шигун М. М. Види звітності підприємств: підходи до їх класифікації / М. М. Шигун, В. О. Іваненко // Проблеми теорії та методології бухгалтерського обліку, контролю і аналізу : міжн. зб. наук. праць ЖДТУ, 2008. - Вип. 3 (12). - С. $432-443$.

15. Король С. Я. Управлінська звітність: сутність і алгоритм формування / С.Я. Король // БізнесІнфом. - 2014. - № 7. - С. 325-327.

16. Гуренко Т.О. Формування внутрішньогосподарської звітності / Т.О.Гуренко, С.І.Деревянко, С.О.Олійник // Науковий вісник Національного університету біоресурсів і природокористування України. - К.: ВЦ НУБіП України, 2012. - Вип. 169: Економіка, аграрний менеджмент, бізнес, ч. 2. - С. 101-107. 
17. Аверчев И.В. Управленчесий учет и отчетность: постановка и внедрение / И.В. Аверчев. - М.: Вершина, 2006. - $512 \mathrm{c.}$

18. Іванюта П.В.. Внутрігосподаський (управлінський) облік у виробничих підрозділах сільськогосподарських господарюючих субєктів / П.В.Іванюта, З.М.Левченко. - К.: Центр навч.літ-ри, 2006. - 368 с.

19. Маренич Т.Г. Внутрішньогосподаська звітність агофомувань в системі управління виробництвом / Т.Г.Маренич // Економіка АПК. - 2005. - №3. - С. 63-71.

20. Управління формуванням конкурентоспроможного потенціалу підприємств (теоретикометодологічний аспект): [монографія] / О.Д. Гудзинський, С.М. Судомир, Т.О. Гуренко ; за заг. ред. О.Д. Гудзинського. - К.: ІПК ДСЗУ, 2010. - 212с.

\author{
Иванченкова Л.В. \\ кандидат экономических наук, доцент \\ E-mail: I.ivanchenkova@mail.ru \\ Ткачук Г.А. \\ кандидат экономических наук, доцент \\ кафедра учета и аудита \\ Одесская национальная академия пищевых технологий \\ ул. Канатная, 112, г. Одеса, Украина, 65039 \\ E-mail: talla2007@ukr.net
}

\title{
ВНУТРИХОЗЯЙСТВЕННАЯ ОТЧЕТНОСТЬ В СИСТЕМЕ УПРАВЛЕНИЯ БИЗНЕСОМ
}

В условиях высокой ритмичности хозяйственных процессов решения необходимо принимать очень быстро, опираясь на внутреннюю информированность. При этом качество управленческой информации играет почти первую скрипку в процессе текущего антикризисного управления бизнесом.

Современная система бухгалтерского финансового учета не в состоянии удовлетворить растущие потребности ее пользователей, поэтому в современном бизнесе растет значение управленческого учета та управленческой (внутрихозяйственной) отчетности.

В данной статье авторами систематизировано отчетную внутреннюю информацию, которую с целью оперативного, текущего и стратегического управления, контроля и планирования должны использовать промышленные предприятия.

В связи с тем, что внутрихозяйственная отчетность предназначена для принятия оперативных управленческих решений, контроля их выполнения, прогнозированием и планированием деятельности и для оценки результатов выполненных решений, поэтому для усовершенствования действующей системы управления авторами предложено разделить весь поток учетно-аналитической инфоомации на три категории:

1. Оперативная внутрихозяйственная (управленческая) отчетность.

2. Текущая внутрихозяйственная (управленческая) отчетность.

3. Обобщающая внутрихозяйственная (управленческая) отчетность.

Состав управленческой (внутрихозяйственной) отчетности для промышленного предприятия, приведенный авторами, поможет обобщить отчетную информацию, которая подлежит обработке в учетно-аналитической системе предприятия и должна быть предоставлена управленцам вместе с аналитическими выкладками (пояснительными записками).

Авторы сделали выводы, что в организации внутрихозяйственной (управленческой) отчетности все еще существуют определенные недостатки, связанные с: отсутствием внешней регламентации; несогласованностью показателей разных фрорм внутрихозяйственной отчетности; отсутствие четкой учетной политики в отношении регламентации внешней отчетности; отсутствие четких принципов корпоративной политики в отношении целей и задач оперативного и текущего управления; недостаточным уровнем осведомленности управленцев по вопросам информативности учетно- 
аналитической системы предприятия (системы учета, анализа и контроля); отсутствие методического обеспечения формирования управленческой отчетности.

Ключевые слова: финансовая отчетность, внутрихозяйственная (управленческая) отчетность, фрункции отчетности, бухгалтерский учет, управленческий учет.

\author{
Ivanchenkova L. \\ Ph.D. in Economics, Associate Professor \\ E-mail: I.ivanchenkova@mail.ru \\ Tkachuk G. \\ Ph.D. in Economics, Associate Professor \\ Department of Accounting and Auditing \\ Odessa National Academy of Food Technologies \\ Kanatna str., 112 , Odessa, Ukraine, 65039 \\ E-mail: talla2007@ukr.net
}

\title{
THE INTERNAL REPORTING SYSTEM FOR BUSINESS MANAGEMENT
}

In conditions of high rhythm of economic processes decisions need to be taken very quickly, relying on the internal informed. Thus quality management information plays almost first fiddle in the process of current antirecessionary management business.

The modern system of accounting of financial accounting is unable to meet the growing needs of its users, so in modern business growing significance of management accounting and management (intraeconomic) statements.

In this article, the authors is systematized the reporting inside information, which for the purpose of operational, current and to strategic management, controlling and planning have to use industrial enterprises.

Due to the fact that intraeconomic reporting is intended for operational management decisions, monitoring their implementation, forecasting and planning activities and to assess of the results of decisions carried out, so for improvement of the existing management system by the authors suggested to divide the entire flow of accounting and analytical information on three categories:

1. Operational intraeconomic (administrative) reporting.

2. Current intraeconomic (administrative) reporting.

3. The generalizing intraeconomic (administrative) reporting.

The structure of the administrative (intraeconomic) reporting for the industrial enterprise given by authors will help to generalize reporting information which is subject to processing in registration and analytical system of the enterprise and has to be provided to managers together with analytical calculations (explanatory notes).

Authors drew conclusions that in the organization of the intraeconomic (administrative) reporting still there are certain shortcomings connected with: lack of an external regulation; inconsistency of indicators of different forms of the intraeconomic reporting; lack of accurate accounting policies concerning a regulation of the external reporting; absence of the accurate principles of corporate policy for the purposes and problems of operational and current management; insufficient level of awareness of managers concerning informational content of registration and analytical system of the enterprise (system of the account, the analysis and control); lack of methodical ensuring formation of the administrative reporting.

Keywords: financial statements, intraeconomic (administrative) reporting, functions of the reporting, accounting, management accounting.

\section{References}

1. Mnykh, I. V. (1997). Stanovlennia i perspektyvy rozvytku suchasnoi systemy bukhhalterskoho obliku i audytu v Ukraini. Svit Bukhhalterskoho Obliku, 1, 32-37.

2. Beradze, L. I., Bondar, T. A., Voronova, M. O., \& Kuzminskoho, I. A. (2007). Bukhhalterskyi oblik dlia 
ekonomistiv i pravoznavtsiv. K., Ukraine: KNEU.

3. Dobrovskyi, V. M. (2001). Zvitnist pidpryiemstv. K., Ukraine: KNEU.

4. Sopko, V. V. (2006). Bukhhalterskyi oblik v upravlinni pidpryiemstvom. K., Ukraine: KNEU.

5. Butynets, F. F., Davydiuk, T. V., Maliuha, N. M., \& Chyzhevska, L. V. (2002). Bukhhalterskyi upravlinskyi oblik (2nd ed.). Zhytomyr, Ukraine: PP «Ruta».

6. Khomyn, P. I. (2004). Formuvannia zvitnosti v pidsystemakh finansovoho, upravlinskoho i podatkovoho obliku. Ternopil, U: Ekonomichna dumka.

7. Storozhuk, T. M. (2012). Vnutrishnohospodarska zvitnist pidpryiemstva. Retrieved from http://www. rusnauka.com/8_NMIW_2012/Economics/

8. Kuznetsova, S. A. (2014). Intehrovana upravlinska zvitnist: Hlobalni vyklyky ta lokalni rishennia v epokhu noosfery. Ekonomichnyi Nobelivskyi Visnyk, 1(7), 270-279.

9. Bakaev, A. S. (2006). Tolkovui bukhhalterskyi slovar. M., Russia.

10. Bryk, H. (2014). Upravlinska (vnutrishnohospodarska) zvitnist ahrarnykh formuvan. Retrieved from Vinau_econ_2014_21(1)_18.pdf-Foxit Reader

11. Tluchkevych, N. V. (2008). Formuvannia systemy vnutrishnoi upravlinskoi zvitnosti v silskohospodarskykh pidpryiemstvakh. Ekonomika APK, 9, 82-88.

12. Pozov, A. K. (2013). Formuvannia vnutrishnohospodarskoi (upravlinskoi) zvitnosti promyslovykh pidpryiemstv. K., Ukraine.

13. Popov, A. N. (2012). Upravlencheskaia otchetnost: Krytycheskyi analyz sushchestvuiushchykh podkhodov y opredelenyi. Fundamentalnue Yssledovanyia, 6, 753-757.

14. Shyhun, M. M., \& Ivanenko, V. O. (2008). Vydy zvitnosti pidpryiemstv: Pidkhody do yikh klasyfikatsii. Problemy Teorii Ta Metodolohii Bukhhalterskoho Obliku, Kontroliu I Analizu, 3(12), 432-443.

15. Korol, S. Ia. (2014). Upravlinska zvitnist: Sutnist i alhorytm formuvannia. 7, 325-327.

16. Hurenko, T. O., Derevianko, S. I., \& Oliinyk, S. O. (2012). Formuvannia vnutrishnohospodarskoi zvitnosti. Ekonomika, Ahrarnyi Menedzhment, Biznes, 169, 101-107.

17. Averchev, Y. V. (2006). Upravlenchesyi uchet y otchetnost: Postanovka y vnedrenye. M., Russia: Vershyna.

18. Ivaniuta, P. V., \& Levchenko, Z. M. (2006). Vnutrihospodaskyi (upravlinskyi) oblik u vyrobnychykh pidrozdilakh silskohospodarskykh hospodariuiuchykh subiektiv. K., Ukraine: Tsentr navch.lit-ry.

19. Marenych, T. H. (2005). Vnutrishnohospodaska zvitnist ahofomuvan v systemi upravlinnia vyrobnytstvom. Ekonomika APK, 3, 63-71.

20. Hudzynskyi, O. D., Sudomyr, S. M., \& Hurenko, T. O. (2010). Upravlinnia formuvanniam konkurentospromozhnoho potentsialu pidpryiemstv (teoretyko-metodolohichnyi aspekt). K.: IPK DSZU

Received 06 February 2016

Approved 20 February 2016

Available in Internet 29.03.2016 